\title{
«Hvis de hadde oppført seg som vanlige nordmenn, hadde alt vært greit, tror jeg» - Nordmenns syn på årsaken til negative holdninger til jøder og muslimer
}

\author{
Vibeke Moe (HL-senteret) \\ vibeke.moe@hlsenteret.no \\ Cora Alexa Døving (HL-senteret) \\ c.a.doving@h/senteret.no \\ Irene Levin (HiOA) \\ Irene.Levin@hioa.no
}

Claudia Lenz (Det Europeiske Wergelandsenteret)

C.Lenz@theewc.org

\section{Keywords:}

antisemitism

islamophobia

anti-Israeli sentiments

prejudice

group-focused enmit@

Norwegian population survey

qualitative analysis 


\begin{abstract}
This article explores contemporary images of Jews and Muslims in Norway by using qualitative empirical data, namely the answers to an open-ended question that was included in a quantitative survey on attitudes towards Jews and other minorities in Norway, conducted in 2012. The target group for the survey consisted of Norwegian residents aged 18 and above. A total of 1522 people answered the questionnaire. The results of the survey can be considered as representative of the Norwegian population with respect to age, gender, education and geographical distribution.
\end{abstract}

Respondents were asked what they regarded to be the reasons for existing negative attitudes towards Jews and Muslims respectively. This article analyzes whether the perceptions reflected in the respondents' answers represent stereotypical views and partly include traces of conspiracy beliefs. The article also discusses these perceptions within the broader perspective of Norwegian society, asking in which ways the data reflects ideas of inclusion and exclusion.

The analysis exposes differences regarding traditional stereotypes and prejudices against the two minorities and the ways in which these prejudices are linked to (perceived) contemporary conflicts and tensions - both within Norwegian society and internationally. Negative attitudes towards Jews are often explained with reference to the role played by Israel in the Middle East conflict, and almost never with specific reference to Norwegian society. The material contains few examples describing Jews as scapegoats for current social problems in Norway. On the contrary, respondents' answers indicate social distance. Approximately half of the answers claim that negative attitudes towards Jews are due to the Israeli-Palestinian conflict. The images of Jews presented in connection with this conflict are predominantly negative and characterized by topics such as oppression, ruthlessness and power. The analysis shows how these statements serve to reduce complexity by effectively equating "Jews" with "Israelis". As a consequence Jews seem to be excluded from the notion of the Norwegian national collective.

The statements about Muslims show that they are regarded to be citizens and as such part of Norwegian society, but with characteristics perceived as problematic and threatening. Respondents often connected negative attitudes towards Muslims with a "foreign culture". Many statements describe Muslims as oppressive to women, as harboring undemocratic attitudes or as criminals.

The data shows how people develop generalizations, describing something as "typically Muslim" or "typically Jewish", reflecting current debates and media coverage. Such generalizations derive their strength from placing the speaker in a morally superior position. In the present material these attitudes represent the antithesis of an implicit notion of the Norwegian community as a liberal, egalitarian and peace-loving society. Despite the differences, a clear picture emerges that the characterizations of both Jews and Muslims seem to serve a common function: to provide a contrast to this national self-image. Such polarized notions of "us" and "them", however, undermine the values generally constructed as "Norwegian": when "the other" bears problematic features that we do not want to acknowledge in ourselves or our communities, we lose the ability to critically reflect on who we are. While maintaining an idealized notion of "us", we become increasingly dependent on a rejection and denial of the "other". 


\section{Innledning}

Denne artikkelen utforsker forestillinger om jøder og muslimer i dagens Norge gjennom en analyse av et kvalitativt materiale fra befolkningsundersøkelsen Antisemittisme i Norge? Den norske befolkningens holdninger til jøder og andre minoriteter (HL-senteret 2012). Undersøkelsen var den første i sitt slag som er blitt gjennomført i Norge. Totalt mottok 3 160 personer invitasjon til å delta, og 1522 besvarte spørreskjemaet. Dette gir en responsrate på 48 prosent. Resultatene fra spørreundersøkelsen kan betraktes som representative for den norske befolkningen med hensyn til alder, kjønn, utdannelse og geografisk tilhørighet. I denne artikkelen er det kun svarene fra to av spørsmålene som skal analyseres. Disse skilte seg fra de øvrige ved å ha åpne svaralternativer. Spørsmålene dreide seg om hva respondentene trodde var årsaken til negative holdninger til jøder og muslimer. Vi har stilt følgende analytiske spørsmål til materialet: Hvilke forestillinger om jøder og muslimer er det som kommer til uttrykk, og hvordan kan vi forstå forskjellene og likhetene i synet på de to gruppene? Hvilke tolkningsmønstre kommer frem? Forteller svarene noe om inkludering og ekskludering i det norske fellesskapet? Forekommer konspirasjonsforestillinger i materialet?

Da datamaterialet ble innsamlet høsten 2011, var det kort tid siden terrorangrepet 22. juli. I kjølvannet av denne hendelsen var rasisme og holdninger til minoriteter mye debattert i norske medier. Hendelsene hadde rystet Norge, og medført en økt oppmerksomhet rundt alvoret som gruppefiendtlige og antidemokratiske holdninger representerer. Samtidig hadde befolkningen erfart at også etniske nordmenn kunne begå terror. Utover angrepet 22. juli var det ingen kriser eller andre større hendelser som kan antas å ha påvirket resultatene.

\section{Et kvalitativt materiale i en kvantitativ undersøkelse}

Den kvantitative delen av befolkningsundersøkelsen ga svar på noen spørsmål, men problemstillinger av mer fortolkende art forble ubesvarte. Analysen av de åpne svarene kan gi en dypere forståelse av hva respondentene anså som årsak til negative holdninger. Denne delen av undersøkelsen ble innledet med at respondentene ble spurt om de trodde negative holdninger til jøder og muslimer var utbredt og om de mente det var nødvendig å gjøre noe for å bekjempe slike holdninger. Resultatene viste at 21 prosent trodde negative holdninger til jøder var utbredt i Norge i dag, mens det tilsvarende tallet for holdninger til muslimer var 87 prosent. Det var flere som mente det var viktig å gjøre noe med antijødiske holdninger (39 prosent) enn de som mente dette var et utbredt problem (21 prosent). Når det gjaldt muslimene var det motsatt. Her var det flere som var av den oppfatning at det var et utbredt problem (87 prosent) enn som syntes det var nødvendig å gjøre noe med saken (61 prosent). Respondenter som uttrykte at negative holdninger var utbredt, ble bedt om å utdype hva de trodde var årsaken til holdningene. ${ }^{1}$ Det er en analyse av svarene som her ble gitt som presenteres i denne artikkelen. Analysen vil samtidig antyde hvordan det kan ha seg at befolkningen hadde så ulike oppfatninger rundt spørsmålet om utbredelse og bekjempelse av de negative holdningene. Umiddelbart kunne en del av forklaringen antas å ligge i den skjellsettende betydning som Holocaust har hatt

1 Svarene fra denne delen av undersøkelsen er altså ikke representative i samme grad som funnene fra befolkningsundersøkelsen som helhet fordi det kun var respondenter som mente at negative holdninger var utbredt som fikk spørsmålene om årsaker. Likevel mener vi at materialet viser noen tendenser som kan si noe om karakteren til eksisterende fordommer. Som et resultat av at det var langt flere som mente at negative holdninger til muslimer var utbredt, var det også langt flere (rundt fire ganger så mange) som svarte på spørsmålet om årsaken til disse holdninger når det gjaldt muslimer $(n=996)$ enn når det gjaldt jøder $(n=253)$. 
for utviklingen av det man kan kalle en mental beredskap mot antisemittisme i Europa. Ved spørsmål om det er viktig å motarbeide antisemittisme, vil mange kunne svare et generelt ja, uavhengig av om de mener slike holdninger er et omfattende problem. En lignende beredskap så ikke ut til å være tilfelle når det var snakk om negative holdninger til muslimer. Som det vil fremkomme av analysen, kan imidlertid respondentenes egne, negative holdninger også ha spilt inn. Selv om materialet i utgangspunktet er et resultat av at respondentene har uttalt seg om årsaker til andres holdninger - et forsøk på å unngå de metodiske vanskeligheter som direkte spørsmål om egne, negative holdninger ville kunne medføre - var mange av svarene formulert som uttrykk for respondentenes egne meninger om minoritetene.

Et første resultat av analysen var at svarene kunne deles i to hovedkategorier når det gjaldt plasseringen av årsaker: Delvis ble årsaken til de negative holdningene plassert hos minoritetene selv, delvis ble de plassert i ytre faktorer (i medienes fremstillinger, trekk ved det norske samfunnet eller hos bærerne av holdningene). Når det gjaldt holdninger til jøder, var fordelingen mellom disse to forklaringsmodellene nokså jevn. Klart færre plasserte imidlertid årsaken til de negative holdningene utenfor gruppen når det gjaldt muslimer. Mange fant altså at muslimene selv var ansvarlige. Kanskje ligger her forklaringen på hvorfor færre mente det var nødvendig à gjøre noe med negative holdninger til muslimer: Hvis problemet oppfattes å ligge hos minoriteten selv, er det mindre omverdenen kan gjøre med saken. Kanskje kan det også forklares med at de som selv har slike meninger ikke ser et behov for å bekjempe dem hos andre. Det ble gjennomført bivariate analyser av materialet som viste noen interessante tendenser $\mathrm{i}$ den retning. Gjennomgående scoret respondentene som hadde besvart de åpne spørsmålene høyere på negative holdninger enn det generelle befolkningsutvalget. ${ }^{2}$

Den kvalitative analysen viste hvordan noen av utsagnene ga uttrykk for motstridende holdninger hos respondentene eller en bevissthet om at fordommene ikke er helt akseptable, såkalt kognitiv dissonans (Festinger 1957). Enkelte av svarene modifiserte også differensieringen av grunner innenfor/utenfor gruppen ved $\stackrel{\circ}{\mathrm{a}}$ vise til at det finnes enkeltpersoner som ødelegger for alle: «Enkelthendelser og personer innenfor en stor gruppe mennesker har skapt vanry». I en del tilfeller ga svarene på denne måten uttrykk for distanse til antisemittisk eller rasistisk fordomsproduksjon. Samlet sett var imidlertid respondentenes holdninger polariserte og svært fo̊ mente at årsaken til holdningene kunne ligge både utenfor og innenfor gruppen.

Siden respondentene kun hadde 100 tegn til rådighet, og en del av svarene bare besto av få ord, gir materialet ikke grunnlag for dypere analyser av den enkelte respondents begrunnelser. Imidlertid gir nettopp denne begrensningen også innblikk i hva de mener er det primære i saken - slik som utsagnet «Kun ett ord: Israel» gir en pekepinn om. Samtidig kan enkle grep, som bruk av anførselstegn, avsløre hvordan respondenten plasserer seg: «Redd for at de skal 'ta over' ...» En del kommentarer kan klassifiseres som såkalte narrative forkortelser («narrative abbreviations», Straub 2005), det vil si henvisninger til det som antas å være en felles referanseramme, for eksempel utsagnet «Bin Laden og 11 . september».

2 Analysen viste videre at personer med fordommer mot jøder i større grad anså den israelsk-palestinske konflikten og egenskaper ved jødene selv som viktige årsaker til utbredelse av negative holdninger til jøder. Samtidig fant de i mindre grad at årsaken lå i egenskaper ved nordmenn eller medienes fremstillinger. Imidlertid var utvalget her lite, noe som gjør resultatene usikre $(n=61)$. Som forventet pekte personer med høy grad av fremmedfrykt i større grad på forhold innenfor gruppen når de skulle forklare utbredelsen av negative holdninger til muslimer. De fant også i større grad at forklaringen lå i kulturelle trekk hos muslimer og i mindre grad at årsaken var å finne i samfunnet rundt. Manglende integrasjon ble også oftere trukket frem som en forklaring blant disse respondentene. 
Gjennom respondentenes beskrivelser dannes et bilde av hvordan muslimer og jøder konstrueres som grupper, enten respondentene uttrykker avstand til dette bildet eller det fremstår som deres egne vurderinger. Materialet vil dermed kunne si noe om rådende forestillinger om jøder og muslimer. Spørsmålstillingens fokusering på negative holdninger innebærer imidlertid at eventuelle positive syn i liten grad er fanget opp.

Første del av analysen omhandler respondentenes svar når det gjaldt negative holdninger til jøder.

\section{DEL I}

\section{«Kun ett ord: Israel» - Betydningen av den israelsk-palestinske konflikten}

Mange respondenter svarte at de trodde negative holdninger til jøder var knyttet til den israelsk-palestinske konflikten. Over halvparten av svarene henviste på forskjellig måte til konflikten eller Israel $(n=253)$. Delvis ble konflikten nevnt som eneste årsak: «Konflikten mellom jøder og palestinere», delvis som del av et mer omfattende svar: «Dels rasisme, dels forholdet til palestinerne.» Rundt en femtedel av svarene trakk frem medienes dekning av konflikten som en kilde til negative syn på jøder. Enkelte nevnte medienes fremstillinger på en måte som kan antas å henspille på den israelsk-palestinske konflikten, men uten noen eksplisitt referanse: «NRK og andre nyhetskanalers feilaktige nyhetsdekning gjennom flere tiår» og «Vestlige mediers dekning av konflikten.»

Som nevnt inneholdt materialet en del utsagn som tematiserte generaliseringer fra enkeltindividers handlinger. Lignende nyanseringer sees i noen av svarene der det refereres til Israel eller mediene: «Staten Israels politikk, eller medienes beskrivelse av denne.» Nyanseringen ligger her først på presiseringen av at det ikke er (alle) jøders handlinger, men Israels politikk som er årsaken til holdningene. Deretter i forbeholdet om at det også kan være medienes fremstillinger som ligger til grunn for holdningene og at årsaken i sin helhet kan ligge «utenfor gruppen». I flere av svarene settes imidlertid et implisitt likhetstegn mellom «jøder» og «israelere»: «Måten de behandler palestinerne på» og «De viser liten vilje til fred med palestinerne. Utvikler apartheid-stat». De uklare skillelinjene viser en tett assosiasjon mellom begrepene. I disse og tilsvarende formuleringer får konflikten et preg av å være en generell jødisk affære: «I konflikten har de vist en veldig fordømmende side og virker ikke som de kan akseptere palestinere.» Gjennom det som ofte bare er et uspesifisert «de» omtales her jøder generelt som aktører i Israel. Dermed blir det også jødene som et kollektiv som er i konflikt med palestinerne og ikke israelske jøder eller den israelske staten. I flere av svarene er begrepet «jøde» i praksis innsnevret til kun å gjelde israelere. Også skillelinjer innad i Israel viskes ut. Bare unntaksvis inneholder utsagnene henvisninger til meningsmotsetninger i befolkningen eller til noe skille mellom et statlig/politisk nivå og sivilbefolkning. Samtidig forekommer det enkelte nyanseringer der nettopp slike generaliseringer blir kritisert: «At folk ikke klarer å skille mellom staten Israel og jøder» eller «Sammenblanding av jødenes rett til egen stat satt opp mot landets politikk». En forklaringsfaktor for tendensen til å gjøre israeleren til en representant for alle jøder kan være at den jødiske befolkningen i Norge er så liten. Medienes fremstillinger vil da ha en sentral funksjon for det bildet som dannes av jøder, og her har den israelskpalestinske konflikten hatt en dominerende posisjon.

Den sentrale betydning som den israelsk-palestinske konflikten gis i materialet er interessant fordi konfliktens relevans for holdninger til jøder var et av kjernespørsmålene i befolkningsundersøkelsen som helhet. Analysen av det kvantitative datamaterialet viste imidlertid at kun respondenter med tydelig antiisraelske holdninger hadde høyere score på 
antisemittisme (HL-senteret 2012:71-73). Respondentenes egne vurderinger gir altså konflikten en viktigere rolle. ${ }^{3}$ Kanskje kan dette føres tilbake til en diskurs som i den norske offentligheten ofte tematiserer en kobling mellom antisemittisme og israelkritikk. Forskere som i dag ser fremveksten av en «ny» antisemittisme knyttet til Israel, ser utviklingen i lys av delegitimeringen av antisemittiske holdninger etter andre verdenskrig: I et samfunn der tradisjonelle antisemittiske ytringer ikke lenger er akseptable, finner holdningene andre uttrykksformer (Bachner 2004; Bunzl 2007). Israel og den israelsk-palestinske konflikten kan gjøres relevant i en antisemittisk diskurs ved at israelkritikken åpner et rom der holdninger kan gis et «legitimt» uttrykk.

Når utsagnene implisitt setter likhetstegn mellom jøder og israelere, fylles samtidig begrepet «jøde» med et bestemt innhold knyttet til konflikten - spesifikt krigføring, militær makt og vold. Karakteregenskaper som stahet og arroganse blir også indirekte relatert til den israelske-palestinske konflikten: «Deres steile holdninger til å oppnå fred». Gjennom den generelle formen som finnes i mange av utsagnene, skapes et inntrykk av at det dreier seg om noe mer enn forholdet til palestinerne, nemlig en dypereliggende, jødisk væremåte. I noen svar knyttes det også an til «historien» i beskrivelsen av en slik kompromissløshet eller stahet: «Står på sitt, tilgir ikke, de vil ikke glemme historien, de overkjører palestinerne». Her preger en «jødisk» stahet både jødenes syn på fortiden og deres handlinger $\mathrm{i}$ dag. En del svar inneholdt slike karakteristikker uten å relatere eksplisitt til den israelsk-palestinske konflikten, men den kan likevel ha vært motiverende for beskrivelsen: «Jøder har dårlig menneskesyn og respekt for andre folkeslag», «Manglende vilje til å anerkjenne andre», «De er så kompromissløse», «Generell uvilje mot å få fred og likhet».

Egenskaper som stahet og arroganse er karaktertrekk som også kan knyttes til tradisjonelle, stereotypiske forestillinger om jøder med en lengre fordomshistorie. Utsagnene konnoterer til den tradisjonelle stereotypien om jøder som sta i eksistensiell forstand, som «nekter å innse» at Jesus er Messias. Med bakgrunn i denne forestillingen har kulturelle representasjoner av jøder fremstilt dem som blinde. ${ }^{4}$ Det er et typisk trekk ved antisemittismen at den på denne måten kombinerer kontinuitet og brudd i forestillingene, der bilder tilpasses aktuelle samfunnssituasjoner og samtidig bærer i seg trekk fra en eldre historie. Robert Chazan beskriver denne dialektikken i Medieval Stereotypes and Modern Antisemitism:

I suggest that in fact every new stage in the evolution of anti-Jewish thinking is marked by dialectical interplay between a prior legacy of negative stereotypes and the realities of a new social context. Out of this interplay emerge novel anti-Jewish perceptions, which in turn become part of the historic tradition of anti-Jewish sentiment. In this way, anti-Jewish thought maintains a measure of stability and continuity, while in fact evolving considerably over the ages. (Chazan 1997:135)

Forholdet mellom kontinuitet og brudd er blitt vektlagt forskjellig innen forskningen på antisemittisme. Der for eksempel Hannah Arendt i The Origins of Totalitarianism la

3 Også i to kvantitative undersøkelser gjennomført av Det Mosaiske Trossamfunn (DMT) uttaler norske jøder at den israelsk-palestinske konflikten er sentral for forekomsten av antisemittisme og negative erfaringer forbundet med à være jøde. Hele 83 prosent av respondentene $\mathrm{i}$ undersøkelsen fra 2012 mener mediedekningen av konflikten i Midt- Østen er meget viktig for utvikling av antisemittisme i Norge de siste ti årene, mens 62 prosent mener «Den vedvarende konflikten i Midt- Østen» er meget viktig (Levin, 2004) (Golombek, Kramer og Levin, 2012).

4 «Synagoga et ecclesia» er betegnelsen på symbolske fremstillinger i middelalderens Europa av den jødiske synagogen og den kristne kirken, gjerne i form av kvinnefigurer på utsiden av kirkebygg eller katedraler. Kjente eksempler finnes ved katedralene i Strasbourg og Bamberg. «Kirken» fremstilles her som seirende over en «synagoge» med bind for øynene. 
tyngdepunktet i sin fremstilling på den aktuelle samfunnsmessige kontekst for den moderne antisemittismens fremvekst (Arendt 2009/1951), står den idéhistoriske kontinuitet i sentrum hos Leon Poliakov og Jacob Katz, selv om ingen av posisjonene, slik Chazan også påpeker, utelukker den andre. I vårt materiale utgjør Israel den dominerende samfunnsaktuelle referansen for negative holdninger til jøder, men fremstillingene preges av ideer med lange tradisjoner i den antijødiske historie.

\section{«Dyktige folk er ikke populært» - Tradisjonelle stereotypier om jøder}

Som vi har sett, forekom en del tradisjonelle stereotypier i materialet, for eksempel når jøder (og israelere) omtales som sta i relasjonen til palestinerne. Et annet karaktertrekk som går igjen i flere av kommentarene, er at jøder på forskjellig vis skulle være særlig «flinke»: «Jødene er flinke til å klare seg sjølve, flinkare enn dei fleste i etterretning.» Også dette er en forestilling med lange tradisjoner i europeisk antijødisk fordomskultur. At egenskapen i dette eksempelet knyttes til etterretning er i så måte en modernisering. Det er rimelig å fortolke dette som nok en referanse til Israel, ved Mossad. I tilknytning til beskrivelser av jødisk «dyktighet» er det også noen som plasserer årsaken til de negative holdningene «utenfor» gruppen, i misunnelse fra omgivelsene. I jantelovens Norge er det bedre à være lik enn dyktig, er det noen som bemerker, for «Dyktige folk er ikke populært.»

Utsagnet «Deres historie som kyniske forretningsfolk» signaliserer i større grad negative holdninger hos respondenten selv. Årsaken til fordommene legges hos jødene, mens bruken av ordet kyniske understreker det negative synet og kan sees som en referanse til forestillingen om jøden som ågerkar. Flere av utsagnene berører den gamle forestillingen om jøden som motivert av det materielle. Også denne forestillingen har en rot i den kristne kulturarven, ikke minst gjennom judasfortellingen. Kun et fătall svar knytter direkte an til antijudaistiske kjernemotiv som kristusmordet: «at de drepte Jesus...». Enkelte refererer til den bibelske fremstillingen av jøder som utvalgte: «Guds utvalgte folk». I det antisemittiske fordomsrepertoaret har denne tanken dannet utgangspunktet for at jøder er blitt stemplet som arrogante. I den kvantitative delen av befolkningsundersøkelsen var det i tråd med en slik holdning $26 \%$ som støttet påstanden om at «Jøder ser på seg selv som bedre enn andre» (HL-senteret 2012:23).

\section{«Hvis de hadde oppført seg som vanlige nordmenn, hadde alt vært greit, tror}

\section{jeg» - Plassering i forhold til det norske samfunnet}

Hva sier så svarene om jødenes plassering i det norske samfunnet? Samlet sett gir svarene svært få fremstillinger der jøder inngår som en del av det norske samfunnet. Mens mange av svarene på forskjellig vis kobler synet på jøder til Israel og den israelsk-palestinske konflikten, er de fleste andre formulert som generelle bemerkninger. I noen tilfeller markeres det derimot en tydelig grense mellom «jøder» og «nordmenn»: «Nordmenn liker ikke folk som er annerledes.» Tyngdepunktet $i$ utsagnet legges her «utenfor» gruppen, $i$ nordmenns fremmedfrykt. Samtidig settes det opp et skille mellom «nordmenn» og «jøder» som (ironisk) understøtter holdningen og gir inntrykk av at jøder er, nettopp, «annerledes». Kommentaren «Hvis de hadde oppført seg som vanlige nordmenn, hadde alt vært greit, tror jeg», går i samme retning. Her er det likevel tydelig at grunnlaget for de negative holdningene legges hos jødene selv, i deres oppførsel. Begge utsagnene har normalitet / ikke-normalitet som utgangspunkt for distinksjonen mellom jøder og nordmenn. Generelt er 
det imidlertid svært få respondenter som begrunner negative holdninger til jøder med fremmedfrykt eller på annen måte tematiserer at jøder er «annerledes».

Utsagnet «Vestlige mediers dekning av konflikten. Nordmenns manglende forståelse av religion. SV og LO» ser en generell motsetning mellom jøder og det norske samfunnet når det gjelder religion. Samtidig kan man ane en viss distanserende holdning til kategorien «nordmenn». Det nære assosiative båndet mellom «israeler» og «jøde» sees igjen ved at det refereres til den israelsk-palestinske konflikten uten nærmere presisering enn «konflikten». Det er interessant at utsagnet indikerer større grad av meningsforskjell når det gjelder «konflikten» enn når det gjelder religion, der «nordmenn» generelt ikke tiltros noen evne til forståelse. En annen respondent indikerte at nettopp det å sette opp et slikt skille mellom «nordmenn» og «jøder» er problematisk: «De bor jo i Norge, de og». Begge utsagn er uvanlige fordi de så tydelig tolker spørsmålet inn i en norsk kontekst. Som nevnt baserte respondentene ellers i påfallende liten grad sine forklaringer på konkrete beskrivelser fra det norske samfunnet. Dette utgjør en tydelig forskjell på de to materialsettene. Holdninger til muslimer ble i stor grad relatert til konkrete samfunnsforhold i Norge. Det er sannsynlig at denne tendensen i det minste delvis kan føres tilbake til at den jødiske minoriteten i Norge er svært liten og at respondentene derfor mangler personlig kjennskap til jøder.

Historisk har anklager om jødisk illojalitet og manglende evne til integrering i samfunnet stått sentralt i antijødisk argumentasjon, også i Norge. Fra opplysningstiden er denne forestillingen formulert som at jøder har en tendens til å danne «stat i staten». ${ }^{5}$ Utsagn i det foreliggende materialet som knytter an til ideer om at jøder er arrogante eller «Guds utvalgte folk» kan kanskje tolkes $\mathrm{i}$ en slik retning, men stoffet mangler direkte henvisninger til at jøder skulle utgjøre en ekskluderende (eller isolert) gruppe i det norske samfunnet. Materialet inneholder heller ikke uttalte konspirasjonsforestillinger om jøder eller påstander om at slike er årsak til negative holdninger. Det betyr ikke at slike forestillinger ikke kan finnes i befolkningen, men de er altså ikke kommet til uttrykk her. Dette utgjør tilsynelatende en diskrepans til funnene i den kvantitative delen av befolkningsunders $\varnothing$ kelsen, der 19 prosent støttet påstanden «Verdens jøder arbeider i det skjulte for å fremme jødiske interesser» (HL-senteret 2012:23). Kanskje finnes det imidlertid spor av slike ideer også i det kvalitative materialet der utsagnene impliserer forestillinger om Israel som en sterk internasjonal makt, en tanke som ofte sees i vår tids konspirasjonsteorier om jøder. Antisemittismeforskningen har vist hvordan fordommer kan overleve i lang tid som del av en kultur med få eksplisitte uttrykk. I en samfunnsmessig krisesituasjon eller når polemisk retorikk spiller på disse latente fordommene kan forestillingene likevel mobiliseres (Zick et al. 2011:31).

\section{«Trodde at de hadde lært av 2. verdenskrig» - Historiens betydning}

Flere av svarene gir uttrykk for at dagens holdninger til jøder baserer seg på en lang historie med fordommer: «Det henger igjen fra gammelt av». Slik vises en bevissthet hos respondentene om antisemittismens lange tilstedeværelse i europeisk kultur, og indirekte den betydning som kulturelt overførte forestillinger om en minoritet har for hvilke holdninger som dannes. For eksempel henvises det til at det å tenke fordomsfullt er et kollektivt fenomen - man tenker negativt om jøder fordi andre gjør det: «Menneskelig flokkmentalitet, jødene har alltid vært syndebukker. Enkelt å skylde på dem.» Jødene

5 For en redegjørelse om betydningen som dette synet hadde i opplysningstidens Europa og for innføringen av adgangsforbudet mot jøder i den norske grunnloven, se Håkon Harket: Paragrafen. Eidsvoll 1814 , Oslo 2014.

V.Moe, C.A Døving, I. Levin, C. Lenz, Nordmenns syn på årsaken til negative holdninger til jøder og muslimer Ambivalence, Vol. 3, No 1/2016 
fortsetter altså å være syndebukker fordi de alltid har vært det. Samtidig er det i dette tilfellet tydelig at respondenten markerer en avstand til en slik mekanisme ved å omtale det som «flokkmentalitet» og «enkelt».

Materialet viser også hvordan jøder assosieres med historiske hendelser, særlig Holocaust. Enkelte utsagn etablerer en tett forbindelse mellom fortid og nåtid der historiske hendelser får direkte implikasjoner for jøder i dag. Ofte går resonnementet i retning av at Holocaust burde ha endret folks holdninger, men at dette ikke har skjedd. Ansvaret for à lære av Holocaust legges likevel særlig på jøder og jødiske israelere: «De behandler palestinere som undermennesker. Trodde at de hadde lært av 2.verdenskrig.» Også her markerer «de» en assosiasjon mellom jøder og israelere. Utsagnet løser opp skillelinjer både historisk og i samtiden: mellom «jøder» og «israeler» og mellom jøder som erfarte 2. verdenskrig og dagens jøder. Fordi «de» selv har vært ofre, burde de vite hvor galt det er å behandle andre slik. Kanskje anes også en historisk forbindelse rent språklig gjennom bruken av ordet «undermennesker» - vanligvis assosiert med nazistenes «Untermensch». Dagens jøder defineres med motsatt fortegn av rollen jødene hadde i Holocaust. Den gang var jødene ofre, nå er de overgripere og okkupanter. Dette er et gjennomgangsmotiv innen antiisraelsk retorikk som også har bredt nedslag i Norge. I den kvantitative delen av befolkningsundersøkelsen var det $38 \%$ som støttet påstanden «Israel behandler palestinerne like ille som jødene ble behandlet under 2 . verdenskrig» (HL-senteret 2012:70).

\section{DEL II}

Svarene på spørsmålet «Hva tror du er årsaken til negative holdninger til muslimer» skiller seg på flere områder fra svarene om holdninger til jøder. En åpenbar forskjell finner vi som nevnt i antall svar (se note 2); fordi langt flere mente at negative holdninger til muslimer var utbredt, er det også langt flere som har blitt spurt om årsaken til disse holdningene. Det var også langt flere som fant at årsaken lå hos muslimene selv fremfor i ytre forhold. Svært få av formuleringene inneholder nyanseringer av typen «mange tror at muslimer...» eller «forestillinger om muslimer som...». Majoriteten av svar består i generaliserte påstander om hvordan muslimene er, det vil si at muslimer tillegges spesifikke naturgitte egenskaper.

Det er også tematiske forskjeller i svarene på holdninger til jøder og holdninger til muslimer. Eksempelvis er referanser til religion utbredt hva gjelder muslimer, mens det er nesten fraværende i svarene når det gjaldt jøder. Direkte referanser til sentrale verdier i det norske samfunnet som likestilling, sekularisme og velferdsstaten inngår også i større grad $\mathrm{i}$ svarene knyttet til muslimer. Negative holdninger forklares da ved at muslimene utgjør en trussel mot disse verdiene. En gjennomgang av hvilke ord som går igjen i svarene gir et illustrerende bilde av i hvilken grad «kultur» og «religion» dominerer. Til tross for at «terror» er det enkeltbegrepet som er brukt av flest respondenter, er mengden av ord som viser til kultur eller religion langt flere (som sharia, kvinnesyn, fundamentalister o.I.). ${ }^{6}$ Nedenfor presenteres hovedtematikken i materialet nærmere.

6 Formuleringer knyttet til terror får flest treff ved et enkelt ordsøk i materialet: 245 respondenter har brukt ordene «terror», «bombing» og «ekstremisme» i sine svar. Ordet «kvinnesyn» er det nest vanligste ordet med 136 treff, og legger vi dette sammen med uttrykk som «kulturen deres», «verdisyn/holdninger» får vi 320 treff tilsammen. Om vi i tillegg ser på svar der «religionen deres», «sharia», «islam» og «koranen» inngår (199 treff) får vi til sammen 501 treff. Om vi i tillegg teller ordet «kriminalitet» der ordet er knyttet til temaer som «utnyttelse av velferdsgoder» sammen med manglende vilje til å bli norske/del av samfunnet/integrering får vi ytterlige 206 årsaksforklaringer der mentalitet/holdninger og verdier hos muslimene kan sies å utgjøre forklaringen. 


\section{«Kvinnehatere. Sharialover» - Kvinnesyn og religion som stereotypisk referanse}

Illustrerende eksempler på formuleringer som vi har definert inn i denne svarkategorien, er: «Kvinneundertrykkelse», «kvinnesynet deres», «omskjæring, æresdrap og at de blander religion og politikk», «sharialover», «voldtekter. Fanatisme», «deres egen holdning til vestlige verdier, demokrati og kvinnesyn», «trangsyn, skremmende menneskesyn, intense holdninger».

Temavalget i svarene gjenspeiler norsk offentlig debatt om islam, der nettopp kvinnesyn har hatt en fremtredende plass. Samtidig kan interessen for «muslimenes manglende likestilling» sees i sammenheng med at islam som religion innehar en klar kjønnsideologi, at flere muslimske miljøer har en kjønnssegregerende kulturell praksis og at kjønnslikestilling som nasjonal kjerneverdi er hegemonisk i den norske debatten. Det er med andre ord i stor grad $\mathrm{i}$ et relasjonelt forhold mellom aspekter ved islam og aspekter ved majoritetssamfunnet at vi finner forklaringen på hvorfor temaet «kvinnesyn» går igjen. Men om vi kan forklare omfanget med referanse til offentlige diskurser, er ikke dette tilstrekkelig som forklaring på voldsomhetene i påstandene. I svar der kvinnesyn dominerer inngår ofte ord som «vold», «voldtekt», «undertrykking» og «kriminalitet», eksempelvis: «All vold og kvinneundertrykking», «Asylsøkere, kriminalitet, synet på kvinner», «Overrepresentert i fengsler, står for mange overfallsvoldtekter, gjenger, kriminalitet, kvinnesyn», «Kvinneundertrykking, brutalitet», «Terror, kvinnesyn, voldtekter, religion». Det er rimelig à anta at vokabularet kjent fra etablerte islamfiendtlige arenaer (Internett), er blitt del av en bredere anti-muslimsk diskurs. I nettkommentarer og blogger er muslimenes behandling av kvinner en retorisk trope der vold og voldtekt gjerne inngår (Døving 2011), og det er rimelig å anta at svarene i vårt materiale er eksempler på påvirkning fra slike antiislamske diskurser.

Sammenlignet med svarene om holdninger til jøder er det påfallende i hvor stor grad dette materialet tematiserer kjønn. Uttrykk som «måten de behandler kvinnene på» viser også at muslimene («de») i stor grad forstås som menn - i utsagnene er mennene bærere av «muslimskheten», mens kvinnene er ofre for den. Som aktører er muslimske kvinner kun til stede som bærere av hijab.

I svarene konnoterer «religion» oftest til fundamentalisme, maktbruk (religion er et verktøy for å utnytte andre) eller ren dumskap. Irrasjonalitet og generelle overskridelser av sosial orden synes å være direkte koblet til forståelsen av muslimenes måte å være religiøse på. I tillegg til dette dumme og emosjonelle inngår det også en referanse til strenghet og fundamentalistisk lydighet når religion omtales: Når «sharia» går igjen i svarene, kobles det ofte til ekstremisme og manglende tilhørighet til demokratiet, eksempelvis: «Fanatiske muslimer, sharialover, terror», «Intet demokrati - skjult sharia». At sharia er en hyppig nevnt årsak til negative holdninger kan ligge i en frykt for alternative lovsystem og for et «samfunn på siden» av det norske demokratiet. Dette kan indikere at muslimer forstås som en politisert enhet, og at dette aspektet gjør dem «truende». Ideen har likhetstrekk med den tidligere nevnte forestillingen om jøder som en «stat i staten». 


\section{«De fleste muslimer er ikke terrorister, men de fleste terrorister er muslimer!» - Terror som sentral referanse}

Svarene der al-Qaida, terror og radikal islam inngår, har en noe større grad av distanse i språket enn de som knyttes til religion og kultur. Det vil si at svar som «islamistiske terrorgrupper» ikke generaliserer muslimer, men oppgir en avgrensing og kan tyde på kunnskap om skillelinjer mellom radikal islam og andre former for islam. I denne kategorien av svar finner vi også formuleringer som påpeker at «noen få ødelegger for mange», eller at «radikale» ødelegger for «moderate». Selv om svarene relatert til terror samlet sett indikerer at kategorien «muslimer» ikke assosieres med terror uten at kategorien differensieres, er det mange eksempler på generaliseringer også her: «pga. de er involvert i så mye negativt terror, slåssing, drap» og «Muslim = terror».

Pnina Werbner argumenterer for at terroristen, eller det hun kaller «den store inkvisitor» (Grand Inquisitor), er den dominerende stereotypien om muslimer i Europa i dag. Bildet rommer en muslim som ønsker underleggelse av alt «vårt» til islam og som ikke skyr terror (Werbner 2014:72-74). Werbner har utvilsomt rett i at terror utført etter år 2000 har skapt et grunnlag for konstruksjonen av en slik figur, men vårt materiale tyder altså på at i Norge veves konstruksjon av muslimen i større grad rundt kultur, verdisyn, kvinnesyn og religion.

\section{«Krever for mye. Vil ikke innrette seg det norske systemet»- Forestillinger om muslimers forhold til demokrati, velferdsstat og integrering}

Omtrent en femtedel av svarene inneholdt referanser til kriminalitet, og flere fremhever uvilje til integrering og motstand mot demokrati: «Utnyttelse av velferdsgoder», «For mange tilpasser seg ikke vestlig kultur, og for mange vil ikke integreres». «Islam er ikke forenlig med demokrati» eller «Muslimene er antidemokratiske». I denne kategorien av svar finner vi også en del referanser til muslimer som en særegen gruppe med ekstra bevilgninger i det norske velferdssystemet: «Får egne særordninger», «Får etablere moskeer nesten hvor som helst».

Tanken om at det eksisterer en nær forbindelse mellom totalitære, antidemokratiske trekk og islam/muslimer samt ideen om at «muslimer har sugerør inn i velferdsstaten» utgjør velkjente bilder fra antimuslimske nettdebatter, blogger og i den såkalte «varslerlitteraturen», som advarer Europa mot islam og muslimer. Det er derfor rimelig å anta at også svarene i denne kategorien er tegn på en mer etablert antimuslimsk diskurs i den norske befolkningen.

\section{«Fordommer, mediedekning» - Majoritetens fremmedfrykt}

Rundt en tredjedel av respondentene plasserer årsaken til de negative holdningene «utenfor gruppen», som uttrykk for trekk ved majoriteten: «fremmedfrykt», «uvitenhet», «lite kunnskap» og «fordommer». Også fremstillinger i «Media» og «FrP» fremkommer som tydelige årsaksforklaringer i materialet - og da ofte av de samme respondentene som trekker frem fremmedfrykt: «Fordommer og dårlig flyktningpolitikk, samt hetspregede utsagn fra politikere, spesielt Frp-ere», eller «vi skjærer alle over en kam» eller «medias dekning». Også i denne kategorien finnes svar av typen «noen få ødelegger for mange». 
Mediene tillegges et stort ansvar som kilde til negative holdninger i befolkningen - og eksempler er både å finne i svarformuleringer som kritiserer majoriteten og i de svar som slår fast dårlige sider ved islam/muslimer. Respondentene nevner særlig medienes fokusering på terror, men også at mediene i for stor grad fokuserer på negative saker eller enkeltmenneskers handlinger og dermed skaper et galt inntrykk av hele den muslimske befolkningen. At det finnes sammenhenger mellom opinionens syn og hva som dekkes $\mathrm{i}$ nyhetene, er vist i forskning (Poole 2002, Morey and Yaqin 2011). Det er likevel noe overraskende at oppfattelsen om at mediene bidrar til å skape negative holdninger er såpass uttalt. I hvilken grad dette kan forklares med en sterk grad av mediebevissthet, det vil si kunnskap om at mediene generelt sett (ikke bare hva gjelder islam) fokuserer på negative hendelser og konflikter, kan ikke utledes av materialet, men burde være et interessant tema for videre forskning.

I en studie av representasjoner av muslimer $\mathrm{i}$ offentligheten fant Morey og Yaqin at muslimer i Vest-Europa presenteres gjennom «refraction, not a reflection of reality» (2011:2-4). Ordene muslim/islam ble ofte gitt en underliggende betydning som «et politisk problem som må løses». Poole, som har typologisert saker islam presenteres gjennom, konkluderte med at uavhengig av om det handler om utdannelse, arbeidsmarked, trosforestillinger, kjønn eller annet, er temaene vinklet på et sammenfallende og repeterende vis $(2002: 64 ; 66)$. Det er et sett temaer som går igjen i de fleste saker om islam og disse er farget av en grunnleggende negativitet (ibid:66). Denne tendensen reflekteres altså i vesentlig grad i svarene fra den norske befolkningen.

På bakgrunn av svarenes karakter har vi antydet at en antimuslimsk diskurs har blitt opinionens diskurs. Det er imidlertid ett tema som har dominert nettdebatter som vi i liten grad finner nedfelt i svarene, nemlig at årsaker til negative holdninger skulle ligge i frykten for at muslimene skal overta landet. Formuleringer om at muslimer făr mange barn, er fraværende, og kun fem av 996 svar forklarer negative holdninger med at «muslimene vil overta styringa». Dette er en parallell til fraværet av konspirasjonsteorier i materialet om holdninger til jøder. Det er interessant at Eurabia-teorien og andre konspirasjonsteorier om muslimer, som har hatt stor innflytelse i blogger og nettdebatter, ikke synes å ha etablert seg som en troverdig forestilling i befolkningen generelt. Det er mulig at fraværet av ideer om den muslimske konspirasjonen kan forklares med at undersøkelsen fant sted etter 22. juli, da nettopp redselen for muslimsk maktovertakelse ble kjent som terroristens hovedmotivasjon og at de som tidligere trodde på konspirasjonen har tatt avstand fra den. En annen forklaring kan være at forestillingene om en planlagt maktovertakelse aldri har forplantet seg som rimelig i større deler av befolkningen, og at denne kun har hørt hjemme i mer ideologiske anti-muslimske miljøer.

Samlet sett gir svarene et klart bilde av «muslimer» som en kategori som rommer lite liberale mennesker, og med særtrekk som dårlig kvinnesyn, tilbøyelighet til kriminalitet og antidemokratiske holdninger. Det tydeligste mønsteret i materialet er hvordan islam og muslimer er knyttet direkte til et skille mellom sekulære, demokratiske verdier og illiberale muslimske verdier. 


\section{Gruppekonstruksjoner: rykter og gjentatte sannheter}

Innledningsvis har vi pekt på sentrale forskjeller i svarkategoriene, blant annet i hvordan årsakene til negative holdninger forklares «i» eller «utenfor» gruppen. En sammenligning av svarene viste også til dels store tematiske forskjeller i respondentenes forklaringer. Samlet sett var det en tendens at respondentene omtalte holdninger til jøder uten å relatere disse til en nær erfaringsvirkelighet og svarene manglet $\mathrm{i}$ stor grad konkrete referanser til det norske samfunnet. Med unntak av henvisningene til den israelsk-palestinske konflikten, var det en generell tendens til at jøder kun ble omtalt i abstraherte eller ikke-konkrete sammenhenger. Samtidig har vi vist til et meningsinnhold som peker mot klassiske antisemittiske fordommer. Referanser til antisemittismens og de antijødiske forestillingenes lange historie var også tydelig som en selvstendig forklaring i respondentenes forståelse. Holdninger til muslimer ble derimot knyttet til begreper som beskriver interne samfunnsproblemer. Tyngdepunktet i svarene trakk en sammenheng mellom «muslimene» og konkrete temaer som negativ oppførsel, kriminalitet, manglende integrasjon og generelt en fremmed kultur. En annen sentral forskjell var som nevnt de mange referansene til verdier og religion i svarene om holdninger til muslimer. Disse temaene spilte ingen pregnant rolle i svarene om jøder. I denne avsluttende delen skal vi imidlertid fremheve likheter fremfor forskjeller i materialet. Dette med referanse til mekanismer som ligger bak gruppekonstruksjonene som begge deler av materialet er preget av.

Gruppekonstruksjoner er generaliserende forestillinger om mennesker der individer betraktes som et kollektiv og nyanser og forskjeller viskes ut. Mens det å tenke i kategorier er en sentral del av kognitive prosesser og en nødvendig følge av et begrepslig språk, har gruppekonstruksjoner gjennom stereotypiseringer klare negative trekk. ${ }^{7}$ I et samfunnsperspektiv kan fordomsproduksjon betraktes som en prosess der mennesker kategoriseres på bakgrunn av kulturelt overførte negative forestillinger. Gruppefokuserte fordommer kjennetegnes av at det felles en negativ dom på bakgrunn av slike (stereotypiske) forestillinger om mennesker som plasseres innenfor en bestemt gruppe. Fordommene kan gjøre seg gjeldende på forskjellige måter, blant annet gjennom ønsker om sosial distanse. All gruppekonstruksjon innebærer imidlertid en grensedragning mellom «oss» og «dem» eller mellom en «inn-gruppe» og en «ut-gruppe». For å belyse hvordan konstruksjonene av den jødiske og den muslimske minoriteten i dette materialet - så forskjellige som de arter seg - bidrar til å konstituere og opprettholde forestillingene om «oss», skal vi avslutningsvis gå til Adorno og hans begrep om antisemittisme som «ryktet om jøden» (Adorno 2001:200). Sentrale trekk ved mekanismene han beskriver, er overførbare til materialet i sin helhet.

Adorno tar utgangspunkt i det at et rykte sirkulerer uten at noen tar ansvar for å ha skapt det. Alle har «hørt noe» eller kjenner noen som kjenner noen som har opplevd noe som bekrefter ryktet. Gjentagelsen og spredningen av ryktet fungerer som bevis for ryktets sannhet. Samtidig er en avkreftelse av ryktet umulig ettersom ingen tar ansvar for innholdet, men kun gjentar hva de har hørt. Hvis det erfares andre handlingsmåter enn de som inngår i ryktet, defineres disse som unntak. På denne måten er ryktet revet løs fra både etterprøvbarhet og beviskrav. Ryktet kan også tilpasses nye omstendigheter og $\mathrm{i}$ samfunnsmessige pressituasjoner fungere som en forklaring på disse.

7 For mer om forholdet mellom kategorier og stereotypier, se for eksempel: Michael Pickering, Stereotyping: Politics of Representation, Suffolk 2001 og Andreas Zick et al. Intolerance, Prejudice and Discrimination, Friedrich Ebert Stiftung, Berlin 2011. 
Forskningen på antisemittisme har pekt på at de antijødiske forestillingene har forandret seg gjennom historien i takt med endrete sosiale, økonomiske og politiske omstendigheter uten å miste sin funksjon: å koble negative elementer $\mathrm{i}$ et samfunn til jødenes åpne eller skjulte innflytelse (Perry/Schweitzer 2008; Heni 2008). Dermed har antisemittismen kunnet forene stikk motsatte påstander om jøder uten å få et logisk problem. På 1920- og 1930tallet kunne eksempelvis forestillingen om den kapitalistiske «pengejøden» leve side om side med forestillingen om «jødebolsjeviken» som i hemmelighet styrte det kommunistiske Russland. Jøden ble både betraktet som «femininisert» - i kontrast til maskuliniteten som nasjonalismen og nazismen dyrket - og samtidig som en seksuell forfører og dermed en trussel mot den «ariske» kvinnens ære (og det «ariske blodet»). Det fantes alltid et element i antisemittismens repertoar som kunne «bevise» at samtlige sosiale, økonomiske og politiske problemer til syvende og sist skyldtes den samme syndebukken: jøden. Tilsvarende finnes eksempler på negative handlinger utført av muslimer, men med en kollektiv referanseramme identifiseres hele gruppen som skyldig.

Den kvantitative delen av befolkningsundersøkelsen viser hvordan enkelte antisemittiske forestillinger, for eksempel påstandene «Jøder har alltid skapt problemer der de bor» og «Jødene har selv mye av skylden for at de er blitt forfulgt», deles av en relativt høy andel respondenter (HL-senteret 2012:23). ${ }^{8}$ Også analysen av det kvalitative materialet har vist hvordan elementer fra det antisemittiske verdensbildet fortsatt sirkulerer. Selv om disse ikke nødvendigvis er knyttet til en bevisst avvisning og fiendtlighet ovenfor jødene som en konkret samfunnsgruppe, er det relevant å spørre om forestillingene kan ha potensial til å mobiliseres - slik dagens situasjon viser i flere andre europeiske land. I materialet som ligger til grunn for denne artikkelen, er det få henvisninger til at jøder fungerer som syndebukker for dagsaktuelle problemer i det norske samfunn. Tvert imot: Utsagn som «arrogante» eller «bare opptatt av seg selv» peker i retning av sosial avstand. Her kan forklaringen være at den jødiske minoriteten i dagens Norge er liten og vel integrert og at visse tradisjonelle fordommer derfor ikke «aktualiseres». Det kan likevel ligge et potensial $\mathrm{i}$ fordommene der de i gitte (konflikt)situasjoner går fra latente, negative forestillinger til manifest hat. «Ryktet» om en gruppe man ikke har mye kontakt med, kan være sosialt akseptert - man gjentar bare det man kjenner fra «hörensagen». Utsagn der jøder kobles til den israelsk-palestinske konflikten har til forskjell fra dette en konkret virkelighetsreferanse. Likevel har ryktet også her som funksjon å redusere kompleksiteten i virkeligheten. Samtidig settes bæreren av fordommen i stand til å ivareta et selvbilde som moralsk intakt - i dette tilfellet er det nærliggende å knytte an til bildet av Norge som en fredsnasjon. Som konsekvens ekskluderes jøder i disse forestillingene fra det norske, nasjonale kollektiv.

Når vi sammenlikner påstandene om jøder og muslimer, er det slående i hvilken grad de negative ytringene om muslimer ikke beskriver dem som en abstrakt størrelse, men som en gruppe som er tydelig til stede $\mathrm{i}$ dagens norske samfunn og gitt egenskaper som problematiske og truende. Vi har analysert en del topoi som peker mot tematikk som i offentlig debatt har blitt definert som verdikonflikter: kvinneundertrykkelse, udemokratiske holdninger og utnyttelse av velferdsgoder. I et representativt utvalg er det imidlertid sannsynlig at mange respondenter ikke har daglig kontakt med muslimer, det er rimelig a anta at offentlighetens og del-offentlighetens islamdebatter utgjør en hovedkilde til holdninger her. Materialet - både hva gjelder jøder og muslimer - vitner om hvordan enkeltreferanser til en offentlig debatt kan slå ut i generaliseringer der elementer fra debattene gjøres til noe typisk «muslimsk» eller «jødisk». Det man har hørt, făr etter hvert status som egen erfaring. Lentin og Titley (2011) beskriver dette som «recited truths»

8 Henholdsvis 14 og 12 prosent.

V.Moe, C.A Døving, I. Levin, C. Lenz, Nordmenns syn på årsaken til negative holdninger til jøder og muslimer Ambivalence, Vol. 3, No 1/2016 
(gjengitte sannheter). Konstruksjonene får sin styrke i kraft av å plassere majoriteten i en moralsk overlegen posisjon. De danner antipodene til en implisitt forestilling om et fredelig, likestilt og trygt norsk fellesskap. Slike polariserte forestillinger om «oss» og «dem» underminerer imidlertid de verdiene som konstrueres som norske: Når den andre blir bærer av de problematiske trekkene som vi ikke vil vedkjenne i oss selv eller vårt samfunn, svekkes samtidig den kritiske selvrefleksjonen. Opprettholdelsen av en idealisert forstilling om «oss» blir i denne mekanismen i økende grad avhengig av negasjonen i forestillingen om den andre. Nettopp slike dikotome prosesser ligger til grunn for stereotypiske forestillinger om jøder og muslimer. 


\section{Referanser}

Adorno, T.W. (2001). Minima Moralia, Berlin/ Frankfurt a.Main (første utgave 1951). Suhrkamp

Arendt, H. (1951). The Origins of Totalitarianism, New York. Harcourt, Brace \& co Bachner, H. (2004). Aterkomsten - Antisemitism i Sverige efter 1945, Stockholm. Natur og kultur

Bergmann, W. og W. Heitmeyer (2005). «Communicating Antisemitism. Are the 'Boundaries of the Speakable' shifting?» Tel Aviv Yearbook og German History 33

Bunzl. M. (2007) Antisemitism and Islamophobia: Hatreds Old and New in Europe, Chicago: Prickly Paradigm Press, sitert i: R. Fine (2009), «Fighting with Phantoms: a contribution to the debate on antisemitism in Europe», Patterns of Prejudice, 43:5, London

Chazan, R. (1997). Medieval Stereotypes and Modern Antisemitism, University of California Press, Berkely/Los Angeles/London

Festinger, Leon (1957). A Theory of Cognitive Dissonance. Stanford, CA: Stanford University Press

Golombek, Rolf, Julian Kramer og Irene Levin (2012). Jødisk liv i Norge: Hva sier DMTs medlemmer i Oslo og Trondheim om deres identitet, tradisjoner, antisemittisme og forholdet til menigheten?, Hatikwa, 5.

Heni, C. (2008). «Secondary Anti-Semitism. From Hard-core to soft-core denial of the Shoah», Jewish Political Studies Review, 20:3-4 (Fall 2008), s. 73-92. Digitalt: http://www.jcpa.org/JCPA/Templates/ShowPage.asp? DBID $=1 \&$ LNGID $=1 \&$ TMID $=111 \&$ FID $=625 \&$ PID $=0 \& I I D=2675$

HL-senteret (2012). Antisemittisme i Norge? Den norske befolkningens holdninger til jøder og andre minoriteter. Red. Vibeke Moe

Langmuir, G.I. (1987). Towards a Definition of Antisemitism, i H. Fein (red.) The Persisting Question. Current Research on Antisemitism, Berlin/New York: de Gruyter http://dx.doi.org/10.1515/9783110858914.86

Lentin, A. og G. Titley (2011). The Crises of Multiculturalism. Racism in a Neoliberal Age. London: Zed books

Levin, Irene 2004, DMTs spørreundersøkelse (DMT's survey), Hatikwa, 1, 2, 3. Morey, Peter og Amina Yaqin (2011). Framing Muslims: Stereotyping and Representation After 9/11, Cambridge, Massachusetts og London: Harvard University Press

Perry, M. og F.M. Schweitzer (2008). Antisemitic Myths. A Historical and Contemporary Anthology, Bloomington/Indianapolis: Indiana University Press

Poole, Elizabeth (2002). Reporting Islam, London og New York: I. B. Tauris

Straub, Jurgen (red.) (2005). Narration, Identity, and Historical Conciousness. New York: Berghahn

Welzer, H. (2005). Täter - Wie aus ganz normalen Menschen Massenmörder werden. Frankfurt/M: S. Fischer Verlag

Werbner, Pnina (2014). «Folk devils and racist imaginaries in a global prism. Islamophobia and Antisemitism in the twenty-first century», i Meer, Nasar (red.) (2014).

Racialisation and Religion: Race, Culture and Difference in the Study of Antisemitism and Islamophobia, London: Routledge 
Zick, Andreas et al. Intolerance, Prejudice and Discrimination, Friedrich Ebert Stiftung, Berlin 2011 